\title{
Invasion of Technology in Education: An Unprecedented Event during COVID 19 Era
}

\author{
Savita Choudhary \\ Department of Management Studies, Swami Keshvanand Institute of Technology, Management \& \\ Gramothan, Jaipur-302017 (INDIA) \\ Email: savitachoudhary@skit.ac.in \\ Received 26.12.2020, received in revised form 01.05.2021, accepted 01.05.2021
}

\begin{abstract}
India has recently announced its latest education policy, known as NEP- 2020. The country is looking forward to educational developments at a faster rate. No doubt, technology has a great role to play in these developments. But since the sudden announcement of nationwide lock down, there was an unprecedented invasion of technology in almost all spheres of life. Education sector is also one of the sectors which were immediately affected in the lock down. Exams could not be conducted, results could not be declared and teaching was also heavily affected. For some days, no one could understand as to what could be done in order to resume the teaching learning processes. After a few days stand still in education industry, then emerged the unprecedented solution of shifting to online mode from physical mode. The solution was embraced in a real hurry. A number of online platforms were tried and different educational bodies adopted these platforms according to their needs and requirements. There was a sudden invasion of technology in education sector and every one had to adapt to it at a real fast pace. The adaption was fast in higher education and later technology took over the school education as well. Probably, premiere institutions and private universities were first to conduct classes through online mode. These became pioneers in using technology for teaching and learning processes during COVID 19 era. This was followed by almost all educational institutions whether private or others. There was no other way to reach out to students and classes were conducted through virtual mode. No one has thought about this transformation, even in the month of March and in April, the teaching learning process went online. This was the most unexpected event in the education industry in the year 2020. All the stakeholders had to resort to this changed mode of delivery process in teaching and learning. Though, it is believed that it would have taken more time in normal situation but the process got expedited due to the attack of COVID 19 pandemic.
\end{abstract}

Keywords- Teaching learning process, Educational delivery, Technology, Education, COVID 19 era

\section{INTRODUCTION}

One fine morning towards the end of March this year, I got up to hear about Janta curfew, to be imposed on March 22, 2020, throughout the country. Well, well, well, what's this Janta curfew? I had never heard of this term before. Google rescued me and I came to know that every Indian citizen would stay indoors for at least fourteen day hours on March 22nd. Again, I thanked myself that I had made no outing plans for this specific Sunday. And then only I realized the damage that could be done by COVID 19, which forced our Honourable Prime Minister to impose Janta curfew and then lock down in the nation. I firmly believe that this step saved many of us from the disease and the death. The term COVID 19 stands for Corona Virus Disease 2019, as it started spreading in the year 2019. The term was not heard before and many conceptions and misconceptions floated about it. Corona virus is off course a deadly virus. There were so many rules and regulations made by the government and imposed over night. One such decision made was to continue the closure of educational institutions, which were already closed after the final exams. This decision was bound to affect the commencement of new session in schools and conduct of final examinations for higher education. To deal with this unprecedented situation, the focus shifted from physical to virtual education system. As there could be no physical teaching and learning on campuses, the system operators and stake holders started looking for newer methods to continue imparting education. This move led to the discovery of various online platforms for the purpose of continuation of teaching and learning process and event conduct of examinations. This way the technology invaded in the education sector, however in almost an unprecedented manner. No one was aware of the consequences of the use of technology in education sector but since there was no other option available, every one resorted to online teaching learning procedures. Though, India was planning to use technology in education sector but the lock down in the country forced stake holders to use the technology in education sector at an immediately faster rate. What was being yearned to be achieved in next five years was achieved in just one month approximately. If not in five years, it might have taken at least another two years. In this manner, it can be said that technology has invaded in the education sector, rather abruptly. All stake holders have welcomed this change and have contributed really positively towards it. Organizations. 


\section{TECHNOLOGY DEFINED}

Let us first try to understand as to what is meant by technology. For completion of any process, generally there is input passing through that process and output is generated at the end of the process. The transformation of input into output requires certain efforts, energy, cost etc. A simple understanding of technology is that the tool or technique that either simplifies the process further to save the resources, increases the output, reduces the input or reduces over all amount of time or cost, is known as technology. Technology is supposed to aid the process such that it reduces human efforts in the overall process. Technology either improves quality or increases quantity. It also focuses on reducing the total time consumption in the process. It can also target on reducing the amount of input or on increasing the amount of output. Technology is about easing the process, in one or the other manner. In education sector, technology would focus on increasing the reach to students, reaching out to distantly placed students, increasing the reach to digital contents, delivery of contents through digital mode, online teaching learning process, conducting various academic activities on online platforms etc. One wonderful advantage of technology is the availability of diversified learning material on various digital platforms on $24 X 7$ basis. Technology definitely increases the accessibility beyond the geographical boundaries and the time limits. Technology reduces or replaces human or physical efforts. The computer has been called "the machine that changed the world". [1]

\section{TECHNOLOGY IN EDUCATION}

There has been considerable shift in the learning paradigm due to the introduction of technology and newer methods of imparting education. New technologies are being gradually integrated into the learning environment. Perhaps it is true that Information technology is the greatest educational revolution. As far as the IT revolution in education is concerned, the Internet allows virtual class rooms, digital libraries provide repositories, the Web offers up to date material for seminar discussions and computer simulation offers an alternative to laboratories. [2]

Education has the history of being delivered physically, since time immemorial. There is a famous saying, 'Guru bingyannahi', meaning that there is no knowledge in the absence of teacher. Education is considered as service and non separability of service and service provider is a unique feature of services. This also implies to teaching as teacher and teaching cannot be separated. But attention may be given to one point that teacher may not be separated from teaching but teacher can be recorded and can be replaced with that recoded teaching material. So once a lecture is recorded, it can be played as many times as needed. Use of technology in imparting education also means that there would be wider reach to students, irrespective of the geographical scattering of students through the globe. Also, there is no physical space limit. The number of learners that can be attached to teacher can be really large. This can give boost to combined classes. Technology can help in preserving the teaching material. Technology can help in online delivery of assignment, tests, quizzes etc. It also helps the students in submitting responses through digital mode. Technology over all increases the efficiency of the whole system, by consuming less time and by increasing the reach. It is the ease of delivery of lessons, either verbal or written. Technology in education also makes it possible to conduct the examinations through various digital platforms. Technology smoothen the processes involved in teaching learning.

\section{ADVANTAGES OF TECHNOLOGY INVASION}

Innovation is like sky diving - fun, scary and risky. The risk can only be minimized by disciplined organization. The levels of innovation risk should parallel the Three Bears' Porridge: not too hot, not too cold. [3]It is not that the physical system of education had many flaws. Still in comparison to physical education system, digital education offers an array of advantages. It tremendously helps in saving resources. The saved resources can be utilized elsewhere. Following are some of the advantages of digitalization of education:

\subsection{Instant accessibility}

Accessibility should be an integral aspect of any education system. There is no doubt that digital resources and more widely, frequently and immediately accessible, in comparison to physical ones. Educational resources are also easily available through digital mode. There are no physical classes. There are virtual classes only which are instantly accessible. This is a great advantage of conducting classes through online mode. Other educational activities like tests, quizzes, assignments, examinations etc. can also be more conveniently administered digitally, in comparison to physical mode.

\subsection{No physical existence}

Teaching and learning is virtual so no physical existence of teacher or students, is needed. No one has to physically reach to the class or the campus. This actually saves a lot of efforts. This allows the teacher to teach from any place and also allows the students to attend the class from any place. Physical collection of all at one place is not required. This has its own benefit. The physical space requirements 
are tremendously decreased as virtual class rooms do not need physical spaces. If the study material is not being stored, the classes being conducted virtually do not require any kind of space at all, neither physical nor digital.

\subsection{One time set up}

Imparting education through virtual mode requires only one time set up. Whichever platform is to be used has to be set up once only. It is unlike physical mode of imparting education, where facilities are required repetitively whenever a class needs to be conducted.

\subsection{Knowledge management}

Using technology in education sector truly encourages knowledge management, which is another area that has evolved during last decade. Knowledge management is the distribution, access and retrieval of human experiences and relevant information between related individuals and work groups. [4]

\subsection{Efforts are saved}

A lot many efforts are saved in terms of delivering the lecture again and again. Large number of learners can join simultaneously. For example, if there are 60 learners per section and if there are 6 sections, all 360 learners can join at a time for the class, which may not be possible otherwise.

\subsection{Travelling is reduced}

A real advantage of online mode of education is the elimination of commuting from one place to another. This saves a lot of efforts and time. It also saves money. And this saved energy can be utilized for the betterment of education, by improving the quality of education.

\subsection{Timeliness}

In online mode, teaching is possible at scheduled time as class must be started on scheduled time. Delays are usually there in physical model. One has to start on time while using online model. Many a times, several activities are scheduled at designated time and such activities start on time. Technology immensely helps in being punctual with academic activities.

\subsection{Learning is possible $24 X 7$}

The biggest advantage of online teaching learning is that teaching learning is possible on $24 \times 7$ basis. Unlike physical delivery of lectures, in online teaching, lectures can be stored in digital form and can be accessed whenever required. There is no limitation of time. In digitalization, the constraints of physical mode are removed.

\subsection{Low cost model}

In comparison to physical delivery model, online mode of imparting education is cheaper. Digital model is a low cost model. It requires initial investment and then operating and maintenance cost only. The operating and maintenance cost is much lesser in comparison to hiring teachers to deliver lectures in physical mode.

\section{ISSUES AND CHALLENGES}

There are two sides of the coin. Similarly, it is not that, that the digitalization of education only has advantages. There are certain issues and challenges as well, related to online teaching and learning. Let us have a look at various issues and challenges pertaining to online mode of education, as following:

\subsection{Technical infrastructure}

The first and foremost challenge related to digitalization of education is the creation of technical infrastructure for imparting education. This may require large initial investments. Creation of technical infrastructure requires the technical expertise. The basic technical infrastructure must be set up, prior to go for digitalization of educational procedures. Three types of soft ware are used viz. System soft ware, Application soft ware and Utility soft ware. [5] All these soft ware need to be used for imparting education digitally.

\subsection{Technical gadgets}

Next issue related to the online education is the requirement of technical gadgets like computer system, lap top, smart phone etc. This also requires substantial funds o the part of the organization or an individual. Also, the learners at the other end need to have some technical gadget in order to receive the learning material, to attend the lectures, to view recorded videos, receive assignments etc. The gadgets need to be of bare minimum technical requirements. At learner level, it may be difficult to afford very high quality technical gadgets.

\subsection{Portal management}

Portals are considered to be virtual workplaces that promote knowledge sharing among different categories of end users such as customers, partners and employees. Portals provide access to structured data stored in data ware houses, data base systems and transactional systems. Portals organize unstructured data such as electronic documents, paper documents, lessons etc. [6] In education sector, portal management can be a challenging issue.

\subsection{Electricity}

The whole system of digitalized education requires electric power. At any end or in between if the 
power supply is interrupted, the system collapses. Continuous power supply is a significant issue related to online education. In our country, there are instances when there are interruptions in power supply. This causes hindrances in online education.

\subsection{Internet}

Another basic requirement in online education is the nonstop requirement of internet facility. Online education consumes a lot of data. Internet may not pose a challenge at organizational front but at an individual level, it is definitely an issue as it involves substantial cost also. The internet is a worldwide, publicly accessible net work of interconnected computer net works that transmit data by packet switching using the standard Internet Protocol. It is a "net work of net works" that consists of millions of smaller domestic, academic, business and government net works which together carry various information and services. [7]

\subsection{Technical know how}

Besides creation of technical infrastructure having knowledge of technology, is also important for online education. This is the biggest challenge as students at different level in different geographical areas. Students of different classes have different level of knowledge regarding technology required for conduct of online classes. Even the teachers are not very much familiar with the programmes to be used for performing different academic activities through digital mode. A teacher is supposed to be expert in his own subject area but he may not be conversant with various technologies to be used for online education. So, learning such technology is also a challenge before educators and learners.

\subsection{Multi user operating system}

Multi user operating system allows two or more users to run programs at the same time. Some multi user operating systems permit even hundreds of users to work concurrently. Here, each user will be provided an independent terminal connected to a single computer system, which can be a main frame or a mini computer, known as server. [8]

\subsection{Maintenance}

The technical infrastructure and gadgets also need regular maintenance. The whole system may collapse in the absence of regular maintenance. The activity of regular maintenance may prove expensive to the organization or to the individual.

\subsection{Licensing issues}

There can be licensing issues with certain applications and soft ware. There can be IPR and copyright issues with such applications. All such issues need to be taken care of.

\subsection{Language}

Language may also serve as a barrier while imparting education digitally. Most of the applications and soft ware are operative in English language while many of the teachers and learners are not conversant with English language. Many are still communicating in either Hindi or even in regional languages.

\section{CONCLUSION}

Change is inevitable. Change does not operate in a vacuum but with in an interactive system which itself is within a wider environment. The change process is helped through a process of observing or being in the system and exploring what works and what does not. [9] COVID 19 has given way to many unprecedented changes in economy and also in various sectors, including education sector. Our country has enormously large education system which includes $\mathrm{n}$ number of schools, colleges, universities, technical institutions, management schools etc. Education sector in our country offers a wide array of qualifications. Indian education sector is not restricted to English language only. It operates in Hindi, Sanskrit and even in regional languages. The sudden outbreak of recent pandemic forced the whole education system to find an alternative to imparting physical education. In the light of the fact that everything was uncertain, education industry strived hard to find a way to continue educational activities. Unlike manufacturing where everything came to a halt, education industry leapfrogged and embraced the changed which was expected may be half a decade ahead. The education industry did not give a second thought while shifting the academic activities online. Digitalization of academic activities was done a real unexpected rate and everyone welcomed this change. With all issues and challenges, today the whole education industry is taking advantage of this unprecedented event that is invasion of technology in education sector. India has definitely taken advantage of this opportunity and has done really well in transforming its education system. Time is not far when our country will have the largest treasure of online learning resources.

\section{REFERENCES}

[1] Lucas Henry C., Jr., Information Technology for Management, 7th edition, Tata McGraw-Hill Publishing Company Limited, New Delhi, $\mathrm{p}-7$.

[2] Sharma Dhiraj, Foundations of IT, 1st edition, Excel Books, New Delhi, $\mathrm{p}-13$.

[3] MaitalShlomo and D. V. R. Seshadri, Innovation Management - Strategies, Concepts and Tools for Growth and Profit, 1st edition, Response Books, New Delhi, p - 34.

[4] Behl Ramesh, Information technology for Management, Tata McGraw - Hill Education Private Limited, New Delhi, $\mathrm{p}-397$.

[5] Bharihoke Deepak, Fundamentals of Information Technology, 3rd edition, Excel Books, New Delhi, p- 187.

[6] Awad M. Elias and Hassan M. Ghaziri, Knowledge 
Management, 2nd impression, Dorling Kindersley (India) Pvt. Ltd., New Delhi, p - 380.

[7] Dixit Vishal and Dr. (Mrs.) Kavaldeep Dixit, Information Technology for Management, 2008, Allied Informatics, Jaipur, p -119 .

[8] Jain Dr. S. C., ShaliniJalan, Sanjay Prakash Ranga and NiteshChouhan, Information Technology, 1st edition, Ramesh Book Depot, Jaipur, p - 4.28

[9] Green Mike, Change Management Masterclass, 1st South Asia edition, Kogan Page India, New Delhi, p-5. 